\title{
Great Expectations: Working Conditions in South Africa Since the End of Apartheid ${ }^{*}$
}

\author{
NiCOLAS PONS-VIGNON \\ (University of the Witwatersrand) \\ WARD ANSEEUW \\ (CIRAD and University of Pretoria)
}

The end of apartheid created great expectations for the majority of South Africans in terms of political, but also social and economic change. At first glance, significant progress has undoubtedly taken place, beginning with the adoption of a very progressive Constitution and legislation protecting civil, economic and social rights. However, 15 years into democracy, after a fourth free general election, many feel that their expectations have not been met and their frustration is turning violent, as demonstrated by several large-scale strikes since 2006. Politically, this frustration has led to a blunt repudiation of the country's leadership during the ANC conference of December 2007 and to Mr. Zuma's ANC unambiguous victory during the 2009 general elections, despite the formation of a breakaway party. This article explores these frustrations through the evolutions that have taken place in the workplace - a central locus of exploitation under apartheid - since the late 1980s; it highlights the necessity of an analysis that goes beyond the sole prism of labour market legislation. Drawing on extensive empirical research, it focuses on the evolution of working conditions in three key sectors of the South African economy - mining, forestry and agriculture. It argues that the post-apartheid era has witnessed a marked increase in the precariousness of workers' status and situations. Despite formal labour market regulation, processes of externalisation have been pervasive, turning previously oppressed wage labourers into poor, casualised workers eking a living in a liberalised economy. South Africa's social and economic policies have decisively contributed to this outcome. The paradox is all the more significant when it is pitted against the high expectations associated with the transition; it epitomises the difficult restructuring of South African society and the uncertainty surrounding its future.

\footnotetext{
* This article draws on empirical results presented in a paper by the same authors, published in Politique Africaine. The latter was however restricted to a description of the evolution of working conditions in three sectors (forestry, mining, agriculture), whereas this article seeks to analyse this evolution in the context of the political transformation (the change of leadership in the ANC and the country) and socio-political violence (numerous violent strikes) with which South Africa is confronted.
} 
South Africa has just had its fourth national elections since its transition from apartheid and white minority rule to multiracial democracy in April 1994. As expected, these were easily won by the African National Congress (ANC). It presently holds nearly 70 per cent of the 400 seats in Parliament and controls eight of the country's nine provinces. However, the elections took place against a backdrop of 18 months of political turmoil as the ANC experienced a degree of internal conflicts and reforms. ${ }^{2}$ The latter was mainly characterised by the ousting of Thabo Mbeki as ANC leader at the party's $52^{\text {nd }}$ National Congress in Polokwane, in December 2007, in favour of his rival, Jacob Zuma, and the subsequent fall of his administration in 2008.

Zuma's election and the entire restructuring of the party's upper echelon the top six positions in the ANC were won by Zuma supporters - came as popular anger mounted against the free market policies of President Thabo Mbeki. With popular mottos such as 'My mother was a kitchen girl, my father was a garden boy, that's why I am a communist' or the famous anti-apartheid struggle song Umshini wami ('give me my machine gun'), he was able to present himself as someone who would be more responsive to the needs of the poor majority, after years of declining living conditions and job prospects. ${ }^{3}$ As such, the South Africa Sunday Times explains, 'Zuma has promised repeatedly to deliver on those expectations-to create jobs, to build houses, to lay water pipes, to revive

\footnotetext{
${ }^{2}$ D. Saks, 'Tough Choices for South Africa', Israel Journal of Foreign Affairs, 3, 2 (2009), pp. 45-51.

${ }^{3}$ B. Bassett and M. Clarke, 'The Zuma Affair, Labour and the Future of Democracy in South Africa', Third World Quarterly, 29, 4 (2008), pp. 787-803.
} 
crippled clinics, to revamp the education, to make the streets safer, to ensure that justice is accessible, effective and equitable, and to guarantee the independence of the watchdogs that guard our rights'. The official unemployment rate would be lowered to 14 per cent by 2014 by creating 1.4 million jobs. There would also be significant improvements in health and welfare benefits: Zuma promised free healthcare for all and an increase of child allocations up to 18 years of age, instead of to 15 as is the case at present. ${ }^{4} \mathrm{He}$ is widely seen as crystallising the hopes of the many South Africans who feel that they have not enjoyed the benefits they expected since the end of the apartheid regime in 1994.

Fifteen years after the end of apartheid, people are indeed still waiting for their living conditions to improve: 34 per cent of the population lives on less than 2 dollars a day, unemployment officially stands at 4.5 million or 25.5 per cent (above 40 per cent if the informal sector is taken into account), and inequality rates are on the rise. ${ }^{5}$ At the same time, a narrow élite associated with the leadership of the ANC has become wealthy and well-integrated into the mainstream 'first world economy', receiving shares in major companies and directorships under the Black Economic Empowerment scheme.

This situation has led to widespread disillusionment with the ANC and mounting violence. In 2006, a three-month strike of South African security workers broke out, resulting in 60 murders committed by striking workers. At the same time, police harassed strikers at every rally they held; they were fired upon during peaceful demonstrations and many were arrested arbitrarily. Protestors built barricades with burning tyres in 2007 over the failure of the ANC to deliver

\footnotetext{
${ }^{4}$ Bassett and Clarke, 'The Zuma Affair', pp. 787-803.

5 Statistics South Africa (SSA), The South African Survey 2008 (Pretoria, SSA, Statistical release, 2008).
} 
new houses. In April and May 2008, a wave of xenophobic attacks against African immigrants in South Africa shocked the world, leaving 62 people dead and thousands injured and causing hundreds of thousands to leave their homes and sometimes the country. ${ }^{6}$ No sooner had the 2009 presidential election celebrations finished than a fresh wave of strikes erupted amongst bus drivers and doctors, with nurses threatening to join them, and thousands of municipal workers suspended from work leaving South Africa's cities dirty and in administrative disarray.

These events are evidence of the deep unrest that South Africa is experiencing. Indeed, Mr. Zuma’s landslide victory over Thabo Mbeki to become ANC President and the violence of the strikes are manifestations of the profound disappointment with the social and economic outcomes of the transition from apartheid. They convey a strong message of growing disenchantment with the 'New' South Africa and a failure to respond to it could endanger future stability.

This article will attempt to shed light on the political economy of South Africa by focusing on an essential cause for frustration among the majority of South Africans, namely their inability to find satisfactory work since 1994. Although the persistence of high unemployment is an essential part of this phenomenon, the article focuses on the evolution of working conditions and argues that, whilst important changes have taken place, exploitation and poor working relations have all but become invisible in a context characterised by outsourcing, casualisation and an increase in the number of foreign workers. Therein lies the South African paradox: the end of white rule, which was strongly associated with wealth accumulation and inequality, created great expectations of

${ }^{6}$ CORMSA (Consortium for Refugees and Migrants in South Africa), Protecting Refugees and Asylum Seekers in South Africa (Johannesburg, 19 June 2008), available at www.cormsa.org.za, retrieved on 27 October 2008. 
social and economic transformation, expectations which, 15 years after the end of apartheid, have for many been unrealised.

In the first section, we emphasise those expectations that were associated with the end of the apartheid workplace regime and the substantial revamping of labour law. In the three sections following this, we look at the changes that have taken place in three selected sectors: mining, forestry and agriculture. Our perspective is firmly rooted in a reliance on case studies as opposed to abstract generalisations derived from large datasets, notwithstanding the latters' value when rooted in a qualitative understanding of their subject - and when the data is reliable. The sectoral diversity of legal regimes, institutional frameworks and economic conditions in the three sectors under apartheid underpinned our decision to analyse the evolution of working conditions in these sectors. Chosen for their historical and economic importance in South Africa (they represented 15 per cent of the working population and 17.7 per cent of GDP in 2005), these sectors were characterised by violent labour relations during apartheid and have subsequently experienced rapid casualisation of labour. They present varying degrees of unionisation and linkage to international capitalism: mining is an industrial sector deeply integrated into the global economy, with historically powerful unions; forestry, a semi-industrial sector integrated into a number of local and global value chains, has seen its rate of unionisation collapse since the beginning of the 1990s; and agriculture, although its production has became more export-oriented, remains characterised by paternalistic labour relations and weak unions. In the last section, we conclude by highlighting how the casualisation of working conditions in South Africa has triggered a crisis of reproduction which 
reveals the striking inadequacy (and probably unsustainable nature) of the transformation of the country's economy.

\section{Great Expectations: Into the Post-Apartheid Workplace Regime}

Social relations of production in contemporary South Africa have been heavily shaped by a violent history. Wage labour regimes have been remodelled by continuous social and political conflicts experienced since the late $19^{\text {th }}$ century. As noted by Makgetla ${ }^{7}$, the apartheid regime (and before this the British and South African colonial regimes) intentionally weakened the position of black capitalists and labourers by maintaining a situation of structural underunemployment, so as to protect the socio-economic position of all whites whilst providing white capitalists with a cheap and tractable black workforce, drawn from an impoverished reserve army of labour. ${ }^{8}$

At the heart of the apartheid political regime lay racially segregated and highly unequal labour rights. Beyond employment opportunities, the panoply of rights that white workers benefited from (union rights, social security, medical insurance, unemployment benefits and access to labour courts) contrasted with the state's efforts to weaken African workers, whether by subverting their organisations or by direct attacks. ${ }^{9}$ White power was such that the assertion of racial domination blurred the lines between productive tasks and personal services. At a 'mixed' workplace, like the Highveld steel factory studied by Von

\footnotetext{
${ }^{7}$ N. Makgetla, 'The challenge of employment and equity in the workplace', in South African Human Rights Commission (SAHRC), Reflections on Democracy and Human Rights: A Decade of the South African Constitution (Johannesburg, SAHRC, 2006), pp.37-53.

${ }^{8}$ H. Wolpe, 'Capitalism and Cheap Labour Power in South Africa: From Segregation to Apartheid', Economy and Society, 1 (1972), pp. 425-56.

${ }^{9}$ Makgetla, 'The Challenge of Employment and Equity in the Workplace'.
} 
Holdt, $^{10}$ a black worker always had to be at the service of a white worker, whether the latter was his superior or not. The professional status of blacks relegated them to the least qualified, most poorly remunerated, jobs; their status did not allow them to contest unfair practices or dismissal, deprived them of indirect wages such as pension or insurance, and of all potential for professional advancement. If employers’ practices allowed it, only the minority of blacks who were in formal employment (from which all temporary workers were excluded) had the capacity to bargain for improved working conditions. ${ }^{11}$

Apartheid generated individual workplace resistance from its outset, but working conditions only started improving in the wake of the violent strikes of 1973 in Durban. Von Holdt shows how blurring the distinction between racial and technical hierarchies, on top of being inefficient, generated a humiliation and a frustration that played a decisive role in the emergence of unions. Soon individual actions were followed by increasingly structured union contestation which pushed the government to adopt the Industrial Conciliation Act of 1979 and to recognise black workers' unions. New rights sparked the extension of conflict in the workplace and beyond, marking a turning point in South African history. The increase in the power of black unions drastically modified the status of wage labour and played a decisive role in the political turmoil that brought about the end of apartheid. Thus, in 1994, when the first democratic elections brought to power a tripartite alliance between the ANC, the South African Communist Party and the Congress of South African Trade Unions (COSATU), ${ }^{12}$

\footnotetext{
${ }^{10}$ K. von Holdt, Transition from Below: Forging Trade Unionism and Workplace Change in South Africa (Pietermaritzburg, University of Natal Press, 2003).

11 Ibid.

${ }^{12}$ In 1983, black union movements were consolidated into a powerful union consisting of more than half a million supporters and 34 unions, COSATU. See E. Webster and G. Adler, 'Towards a Class Compromise in South Africa’s “Double Transition”: Bargained Liberalisation and the
} 
there were great hopes that they would improve living and working conditions for the majority of South Africans. In 1995, the Labour Relations Act (LRA) restructured the relationships between employers and employees. Two years later, in 1997, the Basic Conditions of Employment Act (BCEA) provided a clear and inclusive definition of an employee, which covered all workers (except the selfemployed) and strictly regulated working conditions (45 working hours per week, 21 days of leave per year, sick leave entitlement, etc). While some of the regulations detailed in the BCEA concern all sectors (unemployment insurance, retrenchment funds, etc), a number of social protection measures (pension funds and different types of insurance) depend on negotiated agreements within each business or branch. It is for this reason that the BCEA provides a mechanism, sectoral determination, which allows the Minister of Labour to intervene in defining the minimum remuneration and working conditions in a given sector if workers are insufficiently unionised to negotiate with their employers. ${ }^{13}$

The legal design of the post-apartheid labour regime reveals its (intended) collaborative nature and bears a striking resemblance to the northern European model of industrial relations. The latter's appeal to COSATU and to the liberation movement at large reflected the popular rejection of what Von Holdt calls the 'apartheid workplace regime' ${ }^{14}$ and signalled a desire to entrench the social gains obtained during the 20 years that preceded the first democratic elections. It is at odds with the market-oriented model promoted by institutions such as the World

Consolidation of Democracy', paper presented at the workshop 'Labour and popular struggles in the global economy’ (New York City, Columbia University, 17 November 1998).

${ }^{13}$ An employer is obliged to recognise a union once the rate of unionisation reaches 50 per cent plus one person. See E. Donnelly and S.R. Dunn, 'Ten Years After: South African Employment Relations since the Negotiated Revolution', British Journal of Industrial Relations, 44, 1 (2006), pp. 1-29.

${ }^{14}$ Von Holdt, Transition from Below. 
Bank and the International Monetary Fund, who followed the South African transition closely and sought to influence it. ${ }^{15}$

Yet, the present political changes and the violence associated with recent strikes and outbursts draw attention to the fact that these changes have not met the social and economic expectations of many poor South Africans. Whilst it is not possible to ignore the progress made with the adoption of a very progressive constitution and subsequent legislation, which enhances the protection of civil, economic and social rights, several dynamics have constrained the awaited improvements of working and living conditions. They will be explored through the description of the evolution of labour conditions within three of South Africa’s main economic sectors.

\section{Mining Affected by Liberalisation and (Sub)contracting}

The mining sector has played a central role in South African history. It was for many years one of the nation's primary employers and it has deeply shaped social relations of production. Accounting for between 15 and 30 per cent of GDP, the mining sector employed respectively 489,000 people in the 1940 s and 758,000 at the beginning of the 1990s, representing on average approximately 10 per cent of South Africa's formal employment. ${ }^{16}$ The capitalisation required to enable extraction led to a concentration of mining capital and ownership in the hands of several large companies which influenced and structured the entire sector, if not the whole economy. ${ }^{17}$ Indeed, since the beginning of the $20^{\text {th }}$ century, the South African economy has been organised around 'a minerals-energy complex'

\footnotetext{
${ }^{15}$ Donnelly and Dunn, 'Ten Years After'.

${ }^{16}$ See Statistics South Africa (SSA), Labour Force Survey (Pretoria, SSA, Statistical Release P0210, 2006).

17 D. Innes, Anglo American and the Rise of Modern South Africa,(London, Heinemann Educational Publishers, 1984).
} 
(MEC), a term coined by Fine and Rustomjee in their landmark study of $1996 .^{18}$ In order to supply this sector with an abundant and cheap workforce, specific social relations of production as well as spatial configurations were developed. These features have been exhaustively detailed in numerous studies and so we will do no more than mention briefly their key features here. The division of labour and tasks was strongly related to race, as illustrated by the separation between white 'miners' (allowed to work with explosives) and black 'mineworkers' (confined to basic tasks such as hand-digging or excavating) going back to the early 1920 s. $^{19}$ This organisation of production was complemented by a system based on migrant labour drawn from rural labour reserves and neighbouring countries (Lesotho and Swaziland, but also Zimbabwe, Botswana and Mozambique). ${ }^{20}$ This spatial structure was integral to the apartheid legal framework ${ }^{21}$ and persisted until $1994 .^{22}$

From the 1970s, the mining sector became increasingly dependent on South African workers as a result of the partial loss of control over foreign labourers (following the independence of several southern African countries) and of the increase in local labour demand, which led to an increase in wage rates (of 320 per cent between 1980 and 1985) in order to compete with other labourintensive sectors. ${ }^{23}$ Combined with the rising value of gold and the growing

\footnotetext{
${ }^{18}$ B. Fine and Z. Rustomjee, The Political Economy of South Africa: From Minerals-Energy Complex to Industrialisation (London, Hurst, 1996).

${ }^{19}$ F.A. Johnstone, Class, Race and Gold: A Study of Class Relations and Racial Discrimination in South Africa (London, Routledge, 1976).

${ }^{20}$ R.E.B. Lucas, 'Mines and Migrants in South Africa', American Economic Review, 75, 5 (1985), pp. 1,094-108.

${ }^{21}$ T.D. Moodie and V. Ndatshe, Going for Gold: Men, Mines and Migration (Johannesburg, Witwatersrand University Press, 1994).

${ }^{22}$ W. Anseeuw, 'La reconversion professionelle vers l'agriculture marchande et politiques publiques. Le case des mineurs du Northern Cape' (PhD Thesis, Université Pierre MendèsFrance, 2004).

${ }^{23}$ J. Wilmot, Our Precious Metal: African Labour in South Africa's Industry, 1970-1990 (London, James Currey, 1992).
} 
power of unions since the early 1980 s, ${ }^{24}$ this situation favoured the emergence of far-reaching demands, which led to sectoral agreements on the distribution of added value and improved working conditions. In addition to higher salaries compared to other sectors, mineworkers generally benefited from well-defined, full-time, indefinite-duration contracts. Indirect salaries and social protection were also important, partially protecting mineworkers against unemployment, illness, disability or dismissal. Labour law covering issues such as working hours or sick leave was respected and health and safety regulations were relatively well observed. Mineworkers often benefited from additional advantages (pension funds, multiple forms of insurance, living and food allowances). ${ }^{25}$

Improvements in working conditions began to be reversed following the restructuring of the sector initiated after the 1987 strike and the liberalisation process of the 1990s. The concomitant decrease in international mineral prices resulted in mines struggling to cover their labour costs, which had risen from 25 per cent to over 50 per cent of overall production costs, initially triggering a substitution of labour with capital. ${ }^{26}$ The South African mining workforce decreased from 750,000 in 1990 to 402,000 in 1999 and 288,400 in $2005{ }^{27}$ Moreover, since the 1990s, the sector has witnessed the emergence of companies adopting new organisational models and outsourcing the workforce en masse.

\footnotetext{
${ }^{24}$ The concentration of the workforce facilitated the organisation of powerful unions. As such, the National Union of Mineworkers, created in 1982 to rally miners, was the most powerful union in South Africa for a long time and constituted an essential keystone of COSATU.

${ }^{25}$ For more information, see V.L. Allen, The History of Black Mineworkers in South Africa, (three volumes) (West Yorkshire, The Moor Press, 1992-2005).

26 J. Hayem, 'Fin d'apartheid en Afrique du Sud: quels enjeux pour l'industrie minière et les mineurs sud-africains?', in J-C. Rabier, Actes du Colloque International « Formes de mobilisation dans les régions d'activités minières» (Lille, Université Lille 1/Ifresi, 24-26 May 2000).

27 Statistics South Africa, Labour Force Survey. The number of miners has since stabilised primarily because of the increases in global demand for titanium and platinum, as well as the increased price of gold.
} 
Facilitated by the liberalisation of the economy, these trends have deeply impacted the working conditions of mineworkers in a number of ways.

First, liberalisation and the withdrawal of the state following the end of apartheid were accompanied by a political desire to undermine the power of oligopolies in the mining sector. With many larger South African companies and conglomerates moving abroad or registering offshore, ${ }^{28}$ the opening of markets allowed the emergence of new, medium-sized, often foreign-owned mining enterprises which generally benefited from temporary licences for mines whose rights they rented from larger South African mining companies. In addition, since 1998, a programme aimed at increasing investment, business creation and employment opportunities has promoted small-scale, mainly black-run mining activities, often on agricultural land and sometimes in the former 'Bantustans'. Such businesses have developed rapidly and, although their production is difficult to quantify, in a study conducted in 2000, Anseeuw estimated that workers employed by these new companies represented 24 per cent of the mining workforce. $^{29}$ All these new companies generally invest in temporary mining activities, the profitability of which mainly depends on a considerable reorganisation of labour. As such, productivity gains are generally realised thanks to a reduction in production costs achieved through the deterioration of working and living conditions of labourers.

Second, outsourcing of labour has developed rapidly; ${ }^{30}$ initially concerning so-called non-core activities such as catering, accommodation and

28 P. Carmody, 'Between Globalisation and (Post) Apartheid: The Political Economy of Restructuring in South Africa', Journal of Southern African Studies (JSAS), 28, 2 (2002), pp. 255-75.

${ }^{29}$ Anseeuw, 'La reconversion professionelle’, p. 155.

${ }^{30}$ E. Webster and R. Omar, 'Work Restructuring in Post-Apartheid South Africa', Work and Occupations, 30, 2 (2003), pp. 194-213; E. Webster and K. Von Holdt (eds), Beyond the 
social services, it is increasingly impacting core productive tasks. Two different types of contracting can be observed in the mining sector. ${ }^{31}$ The first concerns contractors, registered as legal companies that allocate their workers to other companies; thus a labour surplus in one mine can be absorbed by another. In this case, contracting is not a means of circumventing labour laws or branch agreements; nor is it geared to prevent union organising. Instead, it aims to create a more flexible organisation of work. The second concerns contractors who change working conditions for the worse as part of their business approach. Although some mining companies, often as a result of union pressure, have imposed, working conditions more or less comparable to their own on their formal contractors, nevertheless contracting often goes hand in hand with deteriorating working conditions. In this case, contractors, representing both formal as well as non-registered companies, employ workers in poorer, even illegal, labour conditions. Such practices are observed in all types of mining companies, which resort to using these contractors to evade certain legislative requirements and limit union action. In these cases, contracting is mainly a means to change working conditions without having to negotiate with workers or their unions

Recent processes associated with the liberalisation of the mining sector, namely new mining enterprises and subcontracting in the majority of the cases, have thus led to a deterioration of working conditions. These new models are characterised by low investment and intense labour exploitation: lower production costs are achieved through the worsening of labour conditions, which become precarious, and even illegal. Employees are often hired on temporary

Apartheid Workplace: Studies in Transition (Pietermaritzburg, University of KwaZulu-Natal Press, 2005).

${ }^{31}$ Anseeuw, 'La reconversion professionelle'. 
(sometimes daily) contracts. This change goes hand-in-hand with a less advantageous employment status and decreased security, an important reduction in direct (which are neither indexed nor negotiated) and indirect wages, as well as with a degradation of physical working conditions (the 45-hour work week is often not respected). Compared to the initial conditions of large mining companies, Anseeuw estimates that the decrease in direct salaries alone is 65 per cent on average, for increased working hours and more difficult and strenuous tasks. $^{32}$ These workers do not have unemployment (or any other) insurance or pension fund membership and their temporary status does not include holidays or sick leave. In addition, employment often depends on available work and on actual profits: mineworkers are forced to assume part of the business risk of the company. This model of organisation allows employers to access a flexible, cheap and tractable workforce who, in addition, is not in a position to bargain for improvements: labour insecurity discourages mineworkers from joining a union or from attempting to negotiate better conditions. The employees of temporary mine exploitation or of the majority of the subcontracted activities are thus unlikely ever to benefit from current high mineral prices.

While Crush noted that, in 1997, five per cent of coal mineworkers worked for contractors, ${ }^{33}$ Bezuidenhout - emphasising the different contracting behaviour per sub-sector (mines operating on a full calendar basis tend to contract more) - estimated it to be 37 per cent in 2005. On average, Bezuidenhout suggests that, in 2005, the number of workers employed by 'outside' contractors had increased to 122,000 , representing more than 30 per

\footnotetext{
${ }^{32}$ Ibid., pp. 160-165.

${ }^{33}$ J. Crush, 'Contract Migration to South Africa: past, present and future', research report prepared for the Green Paper on International Migration (Kingston, Queen's University, South African Migration Project, 1997), available at www.queensu.ca/samptransform/crush.htm.
} 
cent of the mining workforce, ${ }^{34}$ compared to the 25 per cent in 1999 estimated by Streek. ${ }^{35}$ Half of the contract workers were of foreign origin. The importance of casualisation of work observed in South African mines finds its equivalent in many countries confronted with globalisation, but, as will be demonstrated, liberalisation also has more specific consequences in less integrated and less unionised sectors.

\section{South African Forestry in Crisis: Outsourcing - a Worst-Practice Scenario?}

The South African timber industry developed from the beginning of the $20^{\text {th }}$ century and was the driving force behind the emergence of numerous tree plantations. ${ }^{36}$ In contrast with central Africa, Southern Africa has a modest area under natural forest cover: in 1999, forests represented approximately 0.3 per cent of South Africa. ${ }^{37}$ Plantations constitute of imported species, mainly pine and eucalyptus, which are replanted shortly after felling. Like many South African industries, timber grew first at the service of the mineral-energy complex with demand for timber mostly coming from mining and construction until the 1960s. ${ }^{38}$ The state played a direct role in the establishment of plantations to overcome the risks inherent in this type of investment, where the return takes many years to be realised. From the 1960s onwards, the state supported the growth of the pulp and paper industry through a variety of subsidies and credit

${ }^{34}$ A. Bezuidenhout, 'New Patterns of Exclusion in the South African Mining Industry', in K. Bentley and A. Habib (eds), Racial Redress \& Citizenship in South Africa (Pretoria, HSRC Press, 2008), pp. 179-208

${ }^{35}$ B. Streek, 'Subcontracting Explodes on Mines', Mail \& Guardian, (1-7 October 1999).

${ }^{36}$ The 'timber industry' includes forestry and primary transformation industries (saw mills, pulp and paper etc). The term 'forestry' covers the production cycle of timber, from growing trees (silviculture) to felling, debarking and transport.

${ }^{37}$ J. Mayers, J. Evans and T. Foy, Raising the Stakes: Impacts of Privatisation, Certification and Partnerships in South African Forestry (London, International Institute for Environment and Development, 2001).

${ }_{38}$ W.J.A. Louw, 'General History of the South African Forest Industry', Southern African Forestry Journal, 200 (2004), pp. 77-86. 
facilities, intended in particular for two private companies which have since become global players: Sappi and Mondi, a subsidiary of the Anglo-American Group. Although the expansion of South African plantations was curbed slightly after 1972 in order to regulate their impact on river flows, and in 2003 the timber industry represented added value of 1.35 billion euros (or one per cent of South Africa's GDP), and employed more than 170,000 people, 60,000 of whom were in forestry. ${ }^{39}$ But, since the end of the 1980 s, the sector has been experiencing a crisis, which in turn is linked - as we will see - to the outsourcing of forestry operations.

The contracting-out of forestry operations began in the late 1980s, at the time when urban unrest against the apartheid regime reached rural areas and forestry workers, in large part through the activism of unionised factory (paper and sawmills) workers. ${ }^{40}$ Until 2000, large forestry companies insisted that they relied on contractors to improve productivity, arguing that entrepreneurs would be more productive than managers. ${ }^{41}$ Within a period of just a few years, forestry companies had outsourced their entire operations, encouraging their foresters all white - to set themselves up as contractors. The first to outsource were the pulp and paper giants, Sappi and Mondi, whose activities were integrated vertically 'from stump to mill' traditionally, and who are referred to as growersproducers (GPs). Production of timber was, in effect, traditionally subsidised by that of pulp and paper, both of which had a much higher market value. Thus, by contracting out the most labour-intensive part of their activities, the GPs

${ }^{39}$ D. Chamberlain, H. Essop, C. Hougaard, S. Malherbe and R. Walker, The Contribution, Costs and Development Opportunities of the Forestry, Timber Pulp, and Paper Industries in South Africa (Johannesburg, Genesis, 2005).

${ }^{40}$ N. Pons-Vignon, 'Looking at Globalisation From Below: Outsourcing of Forestry Work in South Africa', paper presented at the Second IIPPE [International Initiative for Promoting Political Economy] International Research Workshop (Procida, 9-12 September 2008)

${ }^{41}$ R. Morkel, 'The Real Reasons for Outsourcing', SA Forestry (April-March 2000). 
effectively transferred their risks to their contractors, paying them for actual production only, without providing any technical assistance. ${ }^{42}$

Forestry, a fortiori when deprived of the support of downstream transformation industries, is a risky activity, marked by low timber prices, very small margins and vulnerability to weather variations (mostly affecting debarking and transportation). The organisation of production in the sector is draconian and profits depend on strict controls of production and costs. Yet, outsourcing was accompanied by an aggressive strategy by the GPs to reduce the remuneration of contractors. They exacerbated a 'race to the bottom' price competition and prevented contractors from collectively negotiating annual remuneration increases, by threatening each of them with the loss of new contracts. ${ }^{43}$ There are no available figures to demonstrate the evolution of the pattern of remuneration of contractors, but it is likely that on average it increased less quickly than inflation from the beginning of the 1990s, thus reducing real income considerably. A study conducted in KwaZulu-Natal, with Mpumalanga South Africa's main forestry province, estimated the bankruptcy rate of contractors to be more than 40 per cent in $2004 .^{44}$ It is emphasised in this study that 'although contracting is in theory about a commercial relationship based on the provision of services, in reality there is a power imbalance between the GPs and the contractors, such that it better resembles an employment relationship’. ${ }^{45}$

The practice by forestry companies of remunerating their contractors as poorly as possible contributed to the development of subcontracting, sometimes

\footnotetext{
${ }^{42}$ N. Pons-Vignon, 'Forestry Workers Buckle Under Outsourcing Pipedream', South African Labour Bulletin, 30, 2 (2006), pp. 27-30.

${ }^{43}$ Ibid.

44 J. Clarke and M. Isaacs, What Role for Forestry in Reducing Poverty? Case Studies in the Forestry Sector (London, International Institute for Environment and Development, 2005).

${ }^{45}$ Ibid., p. 14
} 
'cascading' ${ }^{46}$ or multiple subcontracting (contracting out by contractors), most often outside any formal rules. These new entrepreneurs are usually blacks who work for white contractors and employ unskilled workers, often women and illegal migrants, without a contract. This evolution is paradoxically seen as progressive from the point of view of the national Broad-Based Black Economic Empowerment (BBBEE) policy, which supports the creation of small blackowned businesses as part of a development and poverty reduction strategy. But most of these entrepreneurs struggle to keep their businesses afloat; reimbursing debts accumulated to finance the business is often the main motivation to continue until bankruptcy. Moreover, the difficulties they endure to ensure the reproduction of their means of production often leads to the suffocation of their household income. Small contractors tend to divert resources from the family budget (school fees, food) to pay workers or fix equipment. ${ }^{47}$ In other words, they experience a reproduction squeeze as they exhaust domestic resources (reproduction as labour) in order to keep their businesses afloat (reproduction as capital); they are more akin to the African petty-commodity producers described by Bernstein than to promising capitalists. ${ }^{48}$ The forestry industry has thus suffered greatly from outsourcing: the bankruptcy of many foresters-turnedcontractors has deprived the sector of qualified professionals; productivity and production have declined and the number of criminal acts on plantations (arson, timber theft, etc.) has risen. ${ }^{49}$

This crisis has profoundly affected the forestry workforce, leading to a rapid casualisation of working conditions. The risk that forestry companies are

46 B. Appay, 'Economic Concentration and the Externalization of Labour', Economic and Industrial Democracy, 19, 1 (1998), pp. 161-84.

${ }^{47}$ Pons-Vignon, 'Looking at Globalisation from Below'.

${ }^{48}$ H. Bernstein, 'Farewells to the Peasantry', Transformation, 52 (2003), pp. 1-19.

${ }^{49}$ Pons-Vignon, 'Forestry Workers'. 
unloading onto their contractors is in large part assumed by the workers themselves, who are subjected to task work (that is, they are paid upon completion of a set task rather than of a work day). This practice, common in forestry, has become a means of intolerable exploitation: the task is indexed on the productivity necessary to achieve the production stipulated in the contract between the forestry company and the contractor, rather than on the capacity of workers. Many of them are paid between R300 ${ }^{50}$ and R500 per month for hard and often dangerous labour. The tasks demanded are often beyond workers' physical capacity; moreover, they are usually not given adequate training and lack experience and proper equipment. Their resulting inability to perform the required tasks allows contractors to underpay them and further reduce costs. A frequently-observed mechanism to transfer production risks to workers is the refusal to adapt tasks to changing weather conditions, a determining factor in debarking, since dry bark is very hard to tear. The daily 'task race' pushes workers to take risks, further increasing the danger associated with forestry work. Employers are, however, extremely unwilling to recognise work-related injuries; they often do not pay their insurance contributions and their principal companies threaten not to renew their contract if the number of reported accidents increases. Living conditions in forestry compounds have also deteriorated dramatically due to widespread overpopulation in these 'worker villages', isolated in the middle of plantations, and to the withdrawal of GPs from their direct management. Compound management has also been outsourced, with little supervision as is the case with other forestry activities; workers living in crowded tents are occur frequently in Mpumalanga.

\footnotetext{
${ }^{50}$ At the time of the different research projects, one Rand equalled 0.1 Euro.
} 
In rural areas, until the 1990s, forestry workers formed a sort of proletarian élite compared to workers in agriculture, because they were employed by large companies who had conceded a number of social advantages to them, often as a result of action by workers in transformation industries. Due to the impact of outsourcing, however, forestry has come to be seen as a last resort and transformation industry? many even prefer to work in sugar cane or citrus plantations, where conditions are reputed to be very difficult. All indirect incomes have been cut from forestry workers' wages and the duration of contracts, often based on the contractor's own contract (generally one year), has sometimes been shortened to three months. More and more women and foreigners, often illegal Mozambican, Zimbabwean or Swazi migrants, have replaced the male South African workers who made up the majority of the labour force during the era of vertical integration.

Although union mobilisation played a decisive role in the improvement of working conditions in forestry in the 1980s, its efficiency was linked to an alliance with factory workers, for example in sawmills, who were better organised than plantation workers. The contracting out of forestry operations separated the two groups of workers, and the separation was entrenched in the mid-1990s by COSATU's creation of SAAPAWU (the South African Agricultural, Plantations and Allied Workers Union), which organised agricultural workers together with their counterparts in forestry, previously organised by PPWAWU (the Paper, Printing, Wood and Allied Workers Union). The attempt to organise jointly two of the weakest groups of workers (in forestry and agriculture) in conditions of growing casualisation turned out to be a failure and the union soon collapsed. Membership declined and negotiations with forestry employers were difficult, since the latter, from having been a handful of 
GPs, now comprised hundreds of contractors. Numerous micro-unions, often with questionable practices, appeared in areas left uncovered by COSATUaffiliated unions. In 2004, the failure of SAAPAWU was made apparent by its merger into FAWU (the Food and Allied Workers Union), which to date has been unable to reverse the decline of unions in forestry. The failure of unions to protect forestry workers stems, at least partially, from their divisions, which came about at a time of far-reaching structural change in the organisation of the industry.

The publication, in March 2006, of a forestry sectoral determination ${ }^{51}$ demonstrates the government's recognition of the inability of unions to represent and defend forestry workers. The Minister announced a prohibition on task payment being applied to the entire wage of forestry workers, declaring that the minimum wage was to be given in full and that he would not tolerate employers' arguments that task-based work without a guaranteed minimum wage ensured that 'lazy' workers did what was asked of them. ${ }^{52}$ However, one must doubt that this ministerial determination will have much impact in a sector where the absence of unions and the insecurity of workers ensure that the reporting of violations is unlikely, especially when labour inspectors are notoriously understaffed. ${ }^{53}$ Even so, the fact that state intervention was considered necessary reflects the severity of the problems of working relations in rural areas, as is further documented below.

\section{In the Agricultural Sector, a Failure to Secure Land and Labour}

\footnotetext{
51 Department of Labour, 'Sectoral Determination 12: Forestry Sector' (Pretoria, Government Gazette, 17 March 2006).

${ }^{52}$ Press communiqué published on 15 March 2006 on www.infogov.za/speeches.

${ }^{53}$ Follow-up research on the impact of the determination will be carried out by the author in 2009.
} 
In comparison with forestry and mining, the history of South African agricultural labour is found as much, if not more, in the pattern of land appropriation as it is in labour legislation. Indeed, colonial history and the expropriation of the indigenous population, especially since the Native Land Acts of 1913 and 1936, have shaped working and living conditions. Again, the history of this expropriation is well known and need only be sketched briefly here. As a result of the appropriation of land by white settlers, many non-whites were confined to some 13 per cent of the country made up of small, scattered and infertile pieces of land under communal tenure, often leaving them with the sole option to become sharecroppers on white farmland. ${ }^{54}$ These measures served first the process of land appropriation by whites, leading to the displacement of millions of non-whites, and second, the suffocation of the African peasantry. ${ }^{55}$ Subordinated and deprived of their own economic resources, these populations became a reserve army of labour for white agriculture and industries for which, as we have seen above, a migrant labour system was established. These laws also allowed whites to evict black workers living on their land and so increased the harshness of labour conditions. Sharecropping agreements - considered too generous - were gradually transformed into paid agricultural labour and, in Natal, into 'labour tenancy', a system in which work was supplied in exchange for the right to live on the farm land. ${ }^{56}$

By the end of apartheid, the living conditions of farm workers (whether paid workers or labour tenants) had deteriorated considerably: in addition to the 3.5 million blacks expelled from their land between 1950 and 1980, about 1.4

\footnotetext{
${ }^{54}$ C. Van Onselen, The Seed is Mine: the Life of Kas Maine, a South African Sharecropper 18941985 (New York, Hill and Wang, 1996).

55 M. Legassick and H.Wolpe, 'The Bantustans and Capital Accumulation in South Africa', Review of African Political Economy, 3, 7 (1976), pp. 87-107.

${ }^{56}$ C. Bundy, The Rise and Fall of the South African Peasantry (London, Heinemann, 1979).
} 
million people, during the same period, and an additional 730,000 people in the last ten years of apartheid were expelled from white-owned land. ${ }^{57}$ Until 1994 farm workers did not have the right to organise themselves or to join a union. Their working conditions were poor: onerous tasks and workdays frequently in excess of 12 hours for extremely low wages, which were often paid in kind. The relationships between farm workers and owners were characterised by dependence and paternalism. ${ }^{58}$ Not only was permission to reside on the farm dependent on work, making it liable to be revoked with loss of employment but workers were (and are sometimes still) also dependent on the farmer to provide basic necessities, often creating a cycle of indebtedness.

After 1994, the LRA and BCEA provided legal protection for agricultural workers. Even though no minimum wage was set at the time, they created a general framework for improved employment conditions with, inter alia, the regulation of working hours and the abolition of child labour. Moreover, in order to transform the structure of land ownership in the country, as well as to ensure political, social and economic stability, the government launched a land reform programme. In addition to land transfers, tenure reform aimed to secure land rights for non-whites. To protect agricultural workers' land rights, Parliament passed the Labour Tenants Act (LTA) in 1996 and the Extension of Security of Tenure Act (ESTA) in 1997, which provided a legal framework governing evictions. With the exception of people who had worked and lived for more than 20 years on a farm, however, these laws did not protect workers' residency rights; but nonetheless they guaranteed that a court would control evictions.

\footnotetext{
57 Nkuzi Development Association, 'National Evictions Survey', Briefing to Parliamentary Portfolio Committee for Agriculture and Land Affairs (Pretoria 30 August 2005).

${ }^{58}$ A. Du Toit, 'Farm Workers and the Agrarian Question', Review of African Political Economy, 21, 61 (1994), pp. 375-88.
} 
Subsequently, in July 2003, minimum wages were set according to a sectoral determination: depending on location, they range today from between R872 in rural areas to $\mathrm{R} 950$ in peri-urban areas. ${ }^{59}$

Far from achieving their objectives, however, the new laws are rarely enforced and, in some cases, have had a negative impact on the working and living conditions of farm workers. An increase in evictions has been observed since 1994 in reaction to the implementation of the LRA, ETA and ESTA laws and to the establishment of minimum wages. Nkuzi Development Association estimates that approximately 930,000 farm workers have been evicted since 1994, a 13 per cent increase compared to the ten years preceding the first democratic elections. ${ }^{60}$ According to O’Keefe, citing a study by Social Surveys Africa conducted in 2005, there were 199,611 households evicted from their land compared to 164,185 households benefiting from land reform programmes between 1994 and $2004 .{ }^{61}$ Only one per cent of these evictions was reported and conducted according to proper legal procedures. The majority of those evicted had worked and lived on the land for generations; yet not only did they lose their jobs but also their homes. According to Nkuzi, only eight per cent of those evicted found new work (and therefore new accommodation) as farm workers; 14 per cent moved to the former Bantustans and reserves where access to overcrowded communal land is uncertain; 48 per cent relocated to townships; and 30 per cent were reduced to illegal land occupation. ${ }^{62}$

\footnotetext{
${ }^{59}$ Department of Labour, 'Sectoral Determination 8: Farm worker sector' (Pretoria, Government Gazette, 2 December 2002).

${ }^{60}$ Nkuzi Development Association, ‘National Evictions Survey’, p. 10.

${ }^{61}$ P. O’Keefe, 'South Africa: Nearly One Million Farm Workers Evicted Since 1993’, World Socialist Web Site < www.wsws.org> (24 October 2005).

${ }^{62}$ Nkuzi Development Association, ‘National Evictions Survey’, p. 15.
} 
Despite the development of a union of farm workers (SAAPAWU, which we saw was subsequently integrated into FAWU) since 1994 and which claims to have 300,000 members (most of whom are employed in food-processing industries or catering), there has been little success in improving labour conditions. At least 68 per cent of farm workers live in extreme poverty: in 2004, one year after the implementation of the minimum wage, the average monthly salary of farm workers was estimated at R529 for men and R332 for women, ${ }^{63}$ whilst the South African Human Rights Commission even reported salaries of R60 per month. ${ }^{64}$ Eleven- to twelve-hour working days (without compensation) are common and child labour has not disappeared. The rules concerning health and safety are rarely respected and the living conditions of the majority of workers remain very insecure; many are housed in shacks (often made of corrugated iron) without electricity, running water or sanitation.

Furthermore, the above-mentioned measures implemented to protect workers' rights have often increased tensions between farm owners and farm workers, exacerbating the atmosphere of mistrust and conflict. ${ }^{65}$ In order to prevent workers form joining a union and to avoid the provisions of the LTA and ESTA laws securing workers’ land rights, farm owners have often made living conditions unbearable in order to force workers out: homes have been demolished, electricity and water cut off, and so on. The new measures have also induced changes in practices and accelerated the evolution of the social division of labour. In order to limit the number of workers, farm owners have mechanised their activities and turned to less labour-intensive projects (such as game farms

\footnotetext{
${ }^{63}$ Ibid. p. 5.

${ }^{64}$ SAHRC, Inquiry into Human Rights Violations in Farming Communities (Pretoria, SAHRC, 2003).

${ }^{65}$ See ibid.; and Nkuzi Development Association, 'National Evictions Survey’, pp. 10-14.
} 
for tourism). The use of a seasonal and/or temporary workforce increasingly made up of foreign workers, mostly Zimbabwean and Mozambican (generally employed illegally), has also become more frequent. These illegal workers are victims of abuse that is rarely reported or punished.

Numerous cases of violence, including murder (besides the many farm workers killed since 1994, more than 1,500 landowners and farmers have been murdered $^{66}$ ) have been reported, and are linked to the social demands of the landless and other rural poor, to growing inequality, to poor working and living conditions and to farm labour relations. Because of the link between agricultural work and access to land inherited from apartheid, working conditions determine (even more than in other sectors) the living and reproduction conditions of farm workers and their families. It is against this incredibly harsh background - and in the absence of strong union or political support - that workers’ violence against white farmers should be interpreted.

\section{Unfulfilled Expectations and the Post-Apartheid Disenchantment}

South Africa's transition has had a profound impact on workers, yet has not improved their situation as they had hoped; it has been accompanied by a casualisation of their status and conditions, as demonstrated in the three case studies presented in this article. While the desire to transform an exploitative labour regime, characterised by extra-economic coercion, has been manifest in law, little has been done by the new Government to transform the concrete reality on the ground in the workplace. Employers, on the contrary, have adapted to political change by shifting to economic coercion; thanks to high unemployment,

\footnotetext{
${ }^{66}$ Institute for Security Studies, Report on Farm Attacks, Report of the Committee of Inquiry into Farm Attacks (Johannesburg, ISS, 2003).
} 
in South Africa and in the region, and to casualisation, workers are now weighed down by the dull compulsion of economic forces. The importance of this development cannot be underestimated in a country where violence in working relations was the day-to-day form of racial oppression. Although the advent of democracy met the political expectations of the majority, the protective labour laws adopted by the new Government did not prevent the persistence of exploitation and oppression, disappointing the hopes of most South Africans. The roots of this disenchantment can be found, in the three sectors analysed, in specific dynamics that can be grouped according to two main tendencies, also found across South African society and economy: economic liberalisation and the withdrawal of the state, on the one hand; and the South African specificity of racial segregation, on the other.

Since 1996, although it did not have to implement any structural adjustment plan, South Africa has liberalised its economy and has greatly limited the role of the state with regard to economic intervention. ${ }^{67}$ South Africa's economic actors have adapted in different ways to a post-apartheid situation characterised not only by a new socio-political context, but also by an economic restructuring involving the end of active state support for selected 'national champions' combined with an opening to the international economy. The private sector has responded with a substitution of labour by capital, the creation of temporary enterprises and, most of all, with massive outsourcing, which allowed it to reduce costs and to make working arrangements highly flexible. For

\footnotetext{
67 Although liberalisation began in 1994, after the first democratic elections, with the 'Reconstruction and Development Programme' (marking the end of most industrial and agricultural subsidies and of policies supporting whites), it was accelerated in 1996 with the adoption of the 'Growth, Employment and Redistribution' (GEAR) programme, which has been considered by many to be a self-imposed structural adjustment. See J. Michie and V. Padayachee, 'Three Years After Apartheid: Growth, Employment and Redistribution?', Cambridge Journal of Economics, 22, 5 (1998), pp. 623-36.
} 
domestic employers this was a reaction to what they perceived to be an increase in so-called labour market 'rigidity' linked to a rise in labour costs and workers' rights generally; whilst, at the same time, international investors expressed their reluctance at investing in South Africa for the same reasons. ${ }^{68}$ Yet, from the perspective of African workers, we have observed a rapid casualisation of work and conditions through the increased use of temporary contracts, casual labour and task-based payment. In many sectors a movement towards the restoration of a tractable, un-unionised workforce is at work, which is continuously reducing, through means not always understood by workers (like task-based remuneration), the part of value added allocated to labour, which is forced to assume a growing part of risks. These tendencies are strongest in the mining and forestry sectors, where labour conditions had improved during the years of union and political struggles preceding the end of apartheid. In addition, the 'productive reorganisation' of these sectors was the only option proposed to reduce unemployment and poverty.

This first dynamic (economic liberalisation and the rolling-back of the State) and its implications bears a striking resemblance to the evolution of other economies and runs parallel to a reorganisation of production which lies at the heart of globalisation. Indeed, what makes the current globalisation unique is that production systems have become international. ${ }^{69}$ This change has been allowed by the vertical disintegration of production (and the improvement in

\footnotetext{
${ }^{68}$ H. Bhorat, P. Lundall and S. Rospabe, 'The South African Labour Market in a Globalizing World: Economic and Legislative Considerations', Employment Paper 2002/32 (Geneva, International Labour Organization, 2002).

${ }^{69}$ G. Gereffi, ‘The Global Economy: Organization, Governance and Development', in N. Smesler and R. Swedberg (eds), Handbook of Economic Sociology (Princeton, Princeton University Press and New York, Russell Sage Foundation, 2004).
} 
communication technology), resulting from a will to increase the flexibility of labour and counter the power of unions. ${ }^{70}$ This reorganisation has been facilitated by 'market-friendly' macro-economic policies in South Africa. After a brief initial phase of fiscal largesse (during the Reconstruction and Development Programme) aimed at addressing some of the structural inequalities inherited from apartheid, monetary and even fiscal policies have been very prudent since 1996; the Government even ran an R11-billion budget surplus in 2007.

The case studies, however, reveal a liberalisation with a specifically South African flavour. Although international competition has certainly motivated productive reorganisation, South African employers were equally influenced, particularly in agriculture and forestry, by the fear of seeing yesterday's subordinate workforce demanding and exercising new rights to redress past wrongs. The case studies presented here unambiguously indicate that outsourcing and casualisation have been reactions to this perceived threat and to fears that labour discipline would be impossible to implement in a 'free' workplace regime. Other studies confirm this contention, including one by Bezuidenhout and Fakier $^{71}$ of the contracting-out of cleaning services at Wits University. It is also interesting to note that liberalisation and the withdrawal of the state were the exact opposite of segregationist policies, the main instruments of apartheid. This is one of the main sources of the popularity of liberalisation among the South African élite, both black and white: the apartheid leviathan must be abandoned through a liberal policy that limits state intervention. But the relevance of this hostile rhetoric towards the state can be questioned in a country where social and racial tensions are very high and where the transition has bypassed a

\footnotetext{
${ }^{70}$ Appay, 'Economic Concentration and the Externalization of Labour'.

${ }^{71}$ A. Bezuidenhout and K. Fakier, 'Maria's Burden: Contract Cleaning and the Crisis of Social Reproduction in Post-Apartheid South Africa', Antipode, 38, 3 (2006), pp. 462-85.
} 
transformation of the productive apparatus, social relations and income structure. The implementation of liberal policies further facilitates, in South Africa, the persistence of a racial and social hierarchy in the name of the supposed benefits of the free market. The political and economic orientations adopted and analysed here in the context of the evolution of labour conditions do not demonstrate any will or capacity for profound transformation.

Differing from other countries, where crises have typically been periods characterised by a redefinition of wage relations, leading to the implementation of new relations of production, new management practices of the workforce as well as new forms of consumption, ${ }^{72}$ South Africa witnesses the emergence of new forms of employment that reflect a continuation of racial subordination, without reconfiguring the inherited apartheid wage relations. These new forms of employment, increasing the precariousness of labour, facilitate the sidestepping of restructuring and limit the actual transformation of South African society. The observation of workplace politics highlights social conflicts, whose importance is essential to shed light on the country's economic and political transformation (or lack thereof). It seems somewhat utopian to expect a restructuring of South African society on the basis of limited reforms. The sectors that have few unions (agriculture), or whose unions have lost their will or ability to fight, sometimes because of their proximity with political power, offer good examples: the simple declaration of measures supposed to protect workers’ rights had little effect other than to accelerate the deterioration of working and living conditions of the least protected.

\footnotetext{
${ }^{72} \mathrm{R}$. Boyer, 'Du rapport salarial fordiste à la diversité des relations salariales: Une mise en perspectives de quelques recherches régulationnistes', Série Couvertures Oranges, 14 (Paris, Cepremap, EHESS, 2001).
} 
The casualisation of work is even more worrisome since it is accompanied by a withdrawal of the state and the end of the paternalism of apartheid. As Barchiesi remarks:

Macro-economic paradigms have greatly constrained the government's ability to use state expenditures and social grants to address massive poverty and social inequality arising from the country's deepening employment crisis. The ANC government has, therefore, opted for symbolic compensation by continuously praising wage labour as the cornerstone of social discipline and inclusion. In this way it has, ironically, operated in substantial continuity with apartheid-era social policy discourse. ${ }^{73}$

Because of the historical weakness of social policy and of the persistence of mass unemployment, a strong family- and sometimes community-based solidarity survives in South Africa. Most workers work to support their family. Yet another consequence, difficult to quantify but obviously dramatic, of labour casualisation is that the ability of the employed to save money for their family has been drastically reduced, affecting an important number of (often invisible) dependents and unemployed who rely on this support to survive. For agricultural workers and their families, this even translates into the loss of access to land and housing. Another factor is the increase of the active population linked to the feminisation of the workforce, ${ }^{74}$ and to the high number of foreigners in South Africa. Women and foreigners are replacing the men of the country, who can no longer provide for the needs of their family with reduced income from precarious jobs. The employment crisis - unemployment and casualisation - thus induces a general crisis of social reproduction.

\footnotetext{
${ }^{73}$ F. Barchiesi, 'South African Debates on the Basic Income Grant: Wage Labour and the PostApartheid Social Policy', JSAS, 33, 3 (September 2007), p. 575.

${ }^{74}$ D. Casale and D. Posel, 'The Continued Feminisation of the Labour Force in South Africa: An Analysis of Recent Data Trends', South African Journal of Economics, 70, 1 (2002), pp. 156-184.
} 
The workers described in this article are, in the full sense of the term, the 'working poor'. Their difficulties, shared by a large portion of the population, are not fully acknowledged by policy-makers, who, at best, address this situation with 'accompanying measures'. Improvements in working conditions are also often seen as secondary problems, given the high levels of unemployment, and complaints are silenced by a solemn call for necessary adaptation: work must become more flexible to enhance competitiveness and create (or at least save) jobs. In the words of Bhorat et al.,

(...) the pervasive demands of incorporating an emerging developing economy such as South Africa into the national (sic) global economy is being understood as the most appropriate route towards obtaining sustainable economic growth. ${ }^{75}$

This economic strategy, which has been followed by those who have ruled South Africa since 1994, also reflects the transition compromise struck between the ANC and the large South African conglomerates. ${ }^{76}$ Moreover, the development of black small, medium and micro enterprises through preferential contracting (BBBEE) is imposed like a dogma, as it is perceived to be a component of a necessary trajectory (the creation of a black bourgeoisie), and a vehicle for the transformation of society; it has also, however, increased the flexibility and exploitation of the (mainly black) workforce.

These observations arise from the fact that a trickle-down economic policy discourse has been adopted which distinguishes the so-called successful 'first' from the unsuccessful 'second' economy. ${ }^{77}$ The systematic marginalisation

\footnotetext{
${ }^{75}$ Bhorat et al., 'The South African Labour Market in a Globalizing World', p. 54.

${ }^{76}$ On this subject, see the chapter 'Was the ANC trumped on the economy?', in W.M. Gumede, Thabo Mbeki and the Battle for the Soul of the ANC (Cape Town, Zebra Press, 2005), pp. 67-97.

${ }^{77}$ For more details on the 'first' and 'second' economies, see the proceedings of the 'Living on the Margins' conference in Cape Town in March 2007, particularly A. du Toit and D. Neves, 'In Search of South Africa's Second Economy': Chronic Poverty, Economic Marginalisation and Adverse Incorporation in Mt. Frere and Khayelitsha' (PLAAS Working Paper Series, PLAAS
} 
of poor and exploited people is thus sanitised, with no attempt to counteract the increasing casualisation and vulnerability of labourers. This artificial separation justifies the perpetuation (or the reinvention) of a society where the functional articulation between poverty and wealth (largely through the reproduction of a cheap labour force) is seen as natural and justifiable. Policies to address the labour, economic and social division and inequality - which could undermine the position and health of the 'first economy' - are thus not seen as relevant.

As a result, the improvements of working conditions won during the last years of apartheid, through the pressure of union battles against despotic, often violent, practices, were followed by a casualisation that has exposed workers to the 'dull compulsions of economic forces' (in Marx's terms). This faceless violence, presented as necessary, is one that labourers must impose on themselves. Fifteen years after the end of apartheid, under which labour markets (and society) were segmented by law, it appears, that inequality and the belief in the progressiveness of unfettered markets have perpetuated a dual labour market. ${ }^{78}$ This outcome is strikingly (and tragically) ironic: access to new, longawaited, political rights is concomitant with a collapse of the material means of actually using them! This labour crisis points to the essential and potentially destabilising contradiction of the economic policies that the South African government has followed since 1994, mixing economic liberalism and wilful redistribution. The Polokwane landslide in favour of Jacob Zuma (or possibly against Thabo Mbeki) and recent violence undoubtedly indicate that this model of development is reaching its limits in terms of political toleration.

UWC, Cape Town, 2007); I. Frye, 'The 'Second Economy' as Intellectual Sleight of Hand', Africanus, 37, 2 (2007), pp. 175-91; M. Samson, 'When Public Works Programmes Create 'Second Economy' Conditions', Africanus, 37, 2 (2007), pp. 244-56.

${ }^{78}$ T. Hinks, 'Economic Differences in Terms of Employment Contracts: Evidence from the 1999 October Household Survey’, Policy Brief (Johannesburg, NIEP, 2003). 


\section{NiCOLAS PONS-VIgnON}

Corporate Strategy and Industrial Development [CSID] Research Programme, School of Economic and Business Sciences [SEBS], Private Bag 3, Wits 2050, South Africa. E-mail: nicolas.pons-vignon@wits.ac.za

\section{WARD ANSEEUW}

CIRAD/ Post-Graduate School of Agriculture and Rural Development, University of Pretoria, Pretoria 0002, South Africa. E-mail: ward.anseeuw@up.ac.za 